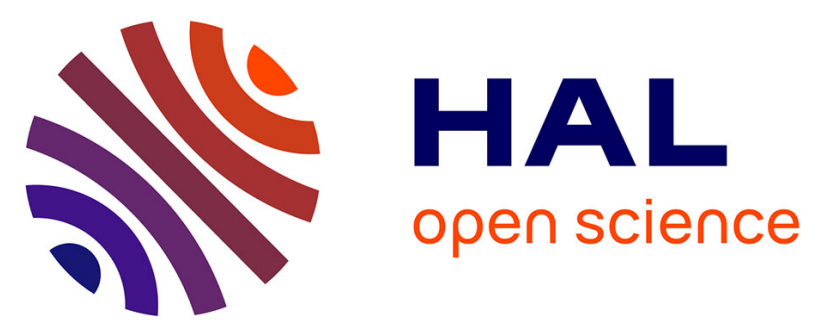

\title{
The SAMCO Web-platform for resilience assessment in mountainous valleys impacted by landslide risks
}

Gilles Grandjean, Loïc Thomas, Séverine Bernardie

\section{To cite this version:}

Gilles Grandjean, Loïc Thomas, Séverine Bernardie. The SAMCO Web-platform for resilience assessment in mountainous valleys impacted by landslide risks. EGU General Assembly 2016, Apr 2016, Vienne, Austria. pp.EGU2016-4312. hal-01254031

\section{HAL Id: hal-01254031 https: / hal-brgm.archives-ouvertes.fr/hal-01254031}

Submitted on 11 Jan 2016

HAL is a multi-disciplinary open access archive for the deposit and dissemination of scientific research documents, whether they are published or not. The documents may come from teaching and research institutions in France or abroad, or from public or private research centers.
L'archive ouverte pluridisciplinaire HAL, est destinée au dépôt et à la diffusion de documents scientifiques de niveau recherche, publiés ou non, émanant des établissements d'enseignement et de recherche français ou étrangers, des laboratoires publics ou privés. 


\title{
The SAMCO Web-platform for resilience assessment in mountainous valleys impacted by landslide risks.
}

\author{
GRANDJEAN G. ${ }^{(1)}$, THOMAS L. ${ }^{(2)}$, BERNARDIE S. ${ }^{(1)}$, VANDROMME R. ${ }^{(1)}$ \& SAMCO TEAM \\ BRGM, Risks and Prevention division, 3 avenue Claude Guillemin, BP36009, 45060 Orléans \\ Cedex 2, France. +33238643482 \\ GEOHYD, 101 Rue Jacques Charles, 45160 Olivet, France, +33 238640207
}

The ANR-SAMCO project aims to develop a proactive resilience framework enhancing the overall resilience of societies on the impacts of mountain risks. The project aims to elaborate methodological tools to characterize and measure ecosystem and societal resilience from an operative perspective on three mountain representative case studies. To achieve this objective, the methodology is split in several points: (1) the definition of the potential impacts of global environmental changes (climate system, ecosystem e.g. land use, socio-economic system) on landslide hazards, (2) the analysis of these consequences in terms of vulnerability (e.g. changes in the location and characteristics of the impacted areas and level of their perturbation) and (3) the implementation of a methodology for quantitatively investigating and mapping indicators of mountain slope vulnerability exposed to several hazard types, and the development of a GIS-based demonstration platform available on the web.

The strength and originality of the SAMCO project lies in the combination of different techniques, methodologies and models (multi-hazard assessment, risk evolution in time, vulnerability functional analysis, and governance strategies) that are implemented in a useroriented web-platform, currently in development. We present the first results of this development task, architecture and functions of the web-tools, the case studies database showing the multi-hazard maps and the stakes at risks. Risk assessment over several area of interest in Alpine or Pyrenean valleys are still in progress, but the first analyses are presented for current and future periods for which climate change and land-use (economical, geographical and social aspects) scenarios are taken into account. This tool, dedicated to stakeholders, should be finally used to evaluate resilience of mountainous regions since multiple scenarios can be tested and compared. 